\title{
Targeting metastatic breast cancer: problems and potential
}

\section{[version 1; peer review: 5 approved]}

\author{
Sarah Deasy ${ }^{1,2 *}$, Karol Szczepanek ${ }^{1 *}$, Kent W. Hunter (iD)1 \\ ${ }^{1}$ Metastasis Susceptibility Section, Laboratory of Cancer Biology and Genetics, Center for Cancer Research, National Cancer \\ Institute, Bethesda, MD, 20892, USA \\ ${ }^{2}$ Institute for Biomedical Sciences, The George Washington University, Washington, DC, 20037, USA \\ * Equal contributors
}

V1 First published: 04 Jun 2015, 4(F1000 Faculty Rev):141

https://doi.org/10.12688/f1000research.6151.1

Latest published: 04 Jun 2015, 4(F1000 Faculty Rev):141

https://doi.org/10.12688/f1000research.6151.1

\section{Abstract}

Breast cancer is one of the leading causes of cancer-related mortality of women in the United States. Since the majority of cancer deaths are due to metastases rather than the primary tumor, a better understanding of the biological mechanisms that lead to metastatic disease is critical to reduce breast cancer associated mortality. Current adjuvant therapies use the same broadly cytotoxic and targeted strategies against metastases as are used against the primary tumor. However, resistance to chemotherapy due to the cellular dormancy, high genotypic and phenotypic heterogeneity between primary tumor and metastases as well as among individual metastases, and the limitations in detection of disseminated tumor cells and micrometastases significantly hinder the efficiency of currently available therapies. While it is crucial to directly address the issue of metastatic dormancy and evaluate for anti-metastatic therapy the relevance of molecular targets chosen based on primary tumor profiling, it is also imperative to address metastasis-specific mechanisms of growth and survival that are likely to be distinct from those of the primary tumor. We believe that a three-pronged approach to therapy will be necessary to deal with progressive disease: blocking of further dissemination after diagnosis; eradication of disseminated tumor cells and prevention of the dormant-toproliferative switch of those remaining; and elimination of established metastatic tumors. The implementation of this strategy requires a greater depth of knowledge of metastasis driver and maintenance genes and suggests the need for a "Metastasis Genome Atlas" project to complement the current investigations into cancer genomic landscapes.

\section{Keywords}

breast cancer, metastatic, metastases, tumor

\section{Open Peer Review}

Approval Status

$\begin{array}{lllll}1 & 2 & 3 & 4 & 5\end{array}$

version 1

04 Jun 2015

1. Patricia Steeg, National Cancer Institute, Bethesda, USA

2. Ann Chambers, London Regional Cancer Centre, London, Canada

3. Suzanne A Eccles, The Institute of Cancer Research, Sutton, UK

4. Danny Welch, University of Kansas Medical Center, Kansas City, USA

5. Robin L. Anderson, Peter MacCallum Cancer Centre, East Melbourne, Australia

Any comments on the article can be found at the end of the article. 
Corresponding author: Kent W. Hunter (hunterk@mail.nih.gov)

Competing interests: No competing interests were disclosed.

Grant information: The author(s) declared that no grants were involved in supporting this work.

Copyright: $\odot 2015$ Deasy S et al. This is an open access article distributed under the terms of the Creative Commons Attribution License, which permits unrestricted use, distribution, and reproduction in any medium, provided the original work is properly cited. The author(s) is/are employees of the US Government and therefore domestic copyright protection in USA does not apply to this work. The work may be protected under the copyright laws of other jurisdictions when used in those jurisdictions.

How to cite this article: Deasy S, Szczepanek K and Hunter KW. Targeting metastatic breast cancer: problems and potential [version 1; peer review: 5 approved] F1000Research 2015, 4(F1000 Faculty Rev):141 https://doi.org/10.12688/f1000research.6151.1

First published: 04 Jun 2015, 4(F1000 Faculty Rev):141 https://doi.org/10.12688/f1000research.6151.1 


\section{Introduction}

Breast cancer remains one of the leading causes of cancer-related mortality among women in the US ${ }^{1}$. Since the primary tumor is usually resected upon detection, the majority of mortality is due to metastases. While 5-year relative survival for patients diagnosed with localized breast cancer is $98.5 \%$, it plummets to a dismal $25 \%$ for patients with distant overt metastases ${ }^{1}$. Moreover, an estimated $20-50 \%$ of breast cancer patients diagnosed at an early stage are expected to develop metastatic disease, which can occur years or even decades after surgical removal of the primary tumor ${ }^{2}$. These statistics indicate that the establishment of effective therapies that target and prevent metastasis is of critical importance. Although the past decade has seen significant advances in the development of methods for detection and treatments of primary breast cancer, these treatments are generally ineffective at eliminating metastatic disease. This suggests either an inherent biological difference between primary tumors and distant metastases, a role of the microenvironment at the secondary site in inducing therapeutic resistance, or likely both.

Recent progress in breast cancer treatment has been characterized by a shift from cytotoxic drugs, which broadly target highly proliferating cells, to more targeted therapies designed to attack a specific molecule or pathway through a known mechanism of action. This approach has been possible due to enormous technological leaps in genome sequencing, molecular biology, cancer genetics, genomics, and bioinformatics that allow for the identification of individual patient mutations and clinically actionable targets from tumor biopsy samples. Sequence information and patient-derived xenograft methods have shown promise in identifying individualized therapeutic strategies that are effective for specific patients, rather than the traditional population-based clinical strategies. However, while various sequencing projects have characterized the genomic landscape of breast cancer ${ }^{3,4}$, relatively little is known about the somatic diversity of metastatic tumors. Expression profiling has revealed multiple subtypes with different prognostic outcomes $^{5}$ and led to identification of gene signatures that can stratify patients into groups with low- or high-risk for developing distant metastatic disease ${ }^{6}$. Still, targeted therapies against metastases have proven to be more challenging to develop compared to those targeting the primary tumor, since the critical driver molecules have not yet been firmly established.

In this review, we discuss the major challenges facing the development of efficient therapies against metastasis. We also present a strategy that we believe will improve the targeting of metastatic disease: blocking of further dissemination after diagnosis, eradication of disseminated tumor cells and prevention of the dormant-to-proliferative switch of those cells not eradicated, and elimination of established metastatic tumors. This strategy requires the elucidation of mechanisms that drive the establishment and maintenance of metastases.

\section{Current anti-metastatic treatments and therapies in development}

Current therapies against metastatic breast cancer address different stages of tumor progression ${ }^{7}$. Broad-spectrum therapies, such as cytotoxic chemotherapy, aim to kill actively dividing cancer cells. According to an extensive meta-analysis, combination chemotherapy can increase the 15-year survival rate of patients with early breast cancer ${ }^{8}$. However, a substantial number of these patients develop metastases or recurrent disease years after cessation of treatment, indicating the presence of dormant cells at the secondary site that are resistant to standard therapies. Therefore, the pathways that allow cancer cells to remain viable in a dormant state would provide ideal targets for eliminating minimal residual disease and preventing metastatic outgrowth after the cessation of treatment. Among them are the survival pathways involving Src and $\mathrm{p} 38^{9-12}$. Recent findings have shown that pharmacological inhibition of Src family kinase (SFK) signaling inhibited the proliferative outgrowth of dormant disseminated cells and the development of macrometastatic lesions ${ }^{12}$. Furthermore, dormant cell proliferation required ERK1/2 activation, and the treatment of cells undergoing the dormant-to-proliferative switch with the combination of Src inhibitor (AZD0530, saracatinib, AstraZeneca) and MEK1/2 inhibitor (AZD6244, selumetinib, AstraZeneca) resulted in apoptosis of dormant cells; neither of the inhibitors alone achieved this effect. Since MEK1/2 is a well-described upstream activator of ERK1/2, these observations complement previous reports showing that an $\mathrm{ERK}^{\mathrm{low}} / \mathrm{p} 38^{\text {high }}$ signaling ratio promotes tumor cell quiescence through a combination of signaling pathways promoting adaptive and basal survival and G0-G1 quiescence ${ }^{11}$. These reports indicate that therapies targeting signaling involved in the dormant-to-proliferative switch might represent promising clinical interventions against metastatic disease.

Major efforts of the pharmaceutical industry are now focused on the development of novel targeted therapies that function in a molecule-specific manner ${ }^{7}$. Examples of targeted therapies that are presently in clinical use for breast cancer are aromatase/estrogen synthase inhibitors (anastrozole, letrozole, and exemestane) ${ }^{13}$ and trastuzumab (Herceptin ${ }^{\circledR}$ ), a monoclonal antibody against epidermal growth factor receptor 2 (ERBB2/HER2/neu) ${ }^{14}$. Initially investigated as a monotherapy and later in combination with chemotherapy, trastuzumab significantly improved patient response rate, time to progression, and overall survival compared to chemotherapy alone $^{14}$. However, its use is limited only to HER2-positive breast cancers, the expression of which, as explained in the next section of this review, may not be constant between primary tumors and metastases, reducing the effectiveness of this strategy.

Based on their specific role in the metastatic cascade, potential molecular targets for therapeutic intervention can be categorized as involved in either metastasis initiation or progression ${ }^{15,16}$. Due to the early dissemination of tumor cells, which is discussed in the next section, molecules important in metastasis initiation, such as regulation of cellular motility, angiogenesis, and invasion of local extracellular matrix (ECM), may not be efficient targets for preventing metastatic disease since patients at risk already have disseminated cells by the time of primary tumor diagnosis. However, if those molecules also play key roles in the later stages (progression) of metastasis, such as continued trafficking after initial escape from the primary tumor ${ }^{17}$, their targeting might be of clinical importance. In particular, molecules that promote survival at the distant sites, the dormancy-to-proliferation switch, and colonization of distant organs are very attractive targets for drug development. 
The molecules identified and currently being investigated comprise both the tumor cell autologous factors, such as those involved in signal transduction, adhesion, motility, growth and survival, and the microenvironmental factors, including resident stromal cells, components of the immune system, chemokines, and promoters of angiogenesis. A growing catalog of potential molecular targets identified for inhibition of metastatic progression has been extensively reviewed ${ }^{7,18,19}$, including a recent overview of drug candidates in current pharmaceutical pipelines that target the mechanisms of tumor cell migration ${ }^{20}$. Effective anti-metastatic therapies need to address metastasis-specific characteristics that allow for the active targeting of metastatic cells. In the next section, we will discuss in more detail the challenges facing the treatment of metastasis from the perspective of drug development, specifically heterogeneity within and between metastases, as well as between metastases and primary tumors, constraints in detection and analysis, and the timing of intervention.

\section{Challenges in the treatment of metastatic disease Dissemination}

The logical approach to preventing metastatic disease is to inhibit the initial dissemination step. Dissemination used to be considered a late-stage event in the linear model of malignant disease evolution, due to the time necessary to accumulate essential somatic mutations required by tumor cells for motility and survival beyond the primary site. However, evidence from mouse models of spontaneous mammary tumorigenesis has shown that tumor cells are able to disseminate to the bone marrow as early as four weeks of age, when mammary tissue only appears in atypical ductal hyperplasia (ADH) or ductal carcinoma in situ (DCIS) stages ${ }^{21}$. Lung micrometastases in the BALB-NeuT model were found at 20 weeks, a full 3 weeks before tumors became visibly invasive. Additionally, early disseminated tumor cells (DTCs) - cells that left the primary tumor and spread to another tissue via the circulation-could be released from growth arrest and had the capability to develop into metastases. The clinical relevance of these findings was confirmed using bone marrow samples from 607 breast cancer patients at various stages of disease, concluding that small tumors produced similar numbers of DTCs to late-stage tumors. Other evidence, including metastasis without invasive cancer such as DCIS ${ }^{22}$, cancers of unknown primary origin ${ }^{23}$, and accidental transfer of cancer from clinically disease-free organ donors ${ }^{24}$ all supported the authors' observations of early dissemination. These reports suggest that breast cancer patients likely have DTCs even before their primary cancer is diagnosed, making the targeting of the origin of metastatic disease a less promising therapy option.

\section{Metastatic dormancy}

One of the major challenges facing oncologists, particularly in the case of breast cancer, concerns DTCs that remain in tissues after adjuvant therapy in a sub-clinical, currently undetectable state, known as dormancy. Upon dissemination, cancer cells can enter dormancy either as individual non-proliferative, quiescent cells or as undetectable micrometastases held in a reduced or balanced proliferative/apoptotic state by lack of adequate resources (angiogenic dormancy) or an active immune system (immunogenic dormancy $)^{25,26}$. These cells or micrometastases can eventually re-emerge and become proliferative years after a patient is thought to be cancer-free. Since the mechanisms of action of many cytotoxic therapies disrupt aspects of the mitotic process, these agents are most likely ineffective against the low or non-proliferative dormant cells ${ }^{27}$. There is also accumulating evidence from experimental models that activated survival mechanisms may be playing a role in protecting DTCs ${ }^{25}$. Regardless of the exact mechanism, DTCs are resistant to the broad-spectrum therapeutic strategies currently in use. Targeted therapy may provide additional benefit, but therapeutic regimens based on the primary tumor may not be effective in DTCs.

\section{Heterogeneity between primary tumor and metastases}

Accumulating evidence indicates that metastases can be genetically and phenotypically different from the primary tumor ${ }^{28}$. This phenomenon has been reported for overt metastases that exhibit the opposite estrogen receptor, progesterone receptor, or HER-2 expression profile of the primary tumor. A meta-analysis examining estrogen receptor, progesterone receptor, and/or HER-2 expression in patients' primary breast tumors and matched recurrent metastases included 48 studies published between 1983 and $2011^{29}$ showing $20 \%, 33 \%$, and $8 \%$ discordance for estrogen receptor, progesterone receptor, and HER-2 status, respectively, with a higher prevalence of positive to negative conversion. The authors suggest that this observation may be the result of individual DTCs reflecting heterogeneity of receptor expression within the primary tumor. Following endocrine therapy, the remaining resistant subpopulations of primary tumor cells are selectively able to disseminate to and grow at secondary sites, producing metastases with a different receptor expression profile than the majority of the original primary tumor. Since treatments are often determined based on the characteristics of the primary tumor, discordance between the primary tumor and metastatic phenotypes can render the treatment ineffective against DTCs. Conversely, some patients with receptor-negative primary tumors but positive metastases may benefit from available targeted therapies but currently are unlikely to receive these therapeutic options due to the clinical characteristics of the primary tumor.

\section{Heterogeneity amongst metastases}

In addition to differences between primary and metastatic tumors, there is also heterogeneity among individual metastases. More than one million cells per gram of tumor can be shed from the primary mass every day ${ }^{30}$ and these cells can come from any of the diverse subpopulations that compose the tumor at any point during tumor evolution. Therefore, the DTCs are a genetically and phenotypically heterogeneous group. However, not all of these cells have the ability to grow into clinically relevant distant lesions, otherwise every patient would have a high metastatic burden. In reality, the metastatic process is incredibly inefficient ${ }^{31,32}$, suggesting a great deal of selective pressure is experienced by DTCs and only those with the proper combination of characteristics are able to successfully colonize a secondary site. Though the successfully metastatic cells probably share many characteristics, the genetic changes that underlie those characteristics may not be identical, resulting in heterogeneity between metastases in addition to differences from the primary tumor ${ }^{33}$. Similar to the evaluation of HER-2 expression between primary tumor and metastases discussed earlier, an investigation into HER-2 expression revealed that $18 \%$ of metastases within the same patient showed discordant expression ${ }^{34}$. In 
another examination of single primary and metastatic breast cancer cells using immunofluorescence in situ hybridization (iFISH), cancer subtype markers, and statistical analysis, investigators measured genetic and phenotypic heterogeneity between distant metastases ${ }^{35}$. These results indicated significant diversity between distant metastases within the same patient. Furthermore, the authors observed substantial differences between metastases in the proportions of cells displaying subtype markers, indicating both genetic and phenotypic differences were prevalent between distant metastases from the same patient.

\section{Pharmacokinetics}

An additional challenge to successful treatment of metastatic disease is the ability to deliver the therapy to the metastatic tumor cells. Metastases are often present in multiple sites within a patient and drug accessibility between tissues, for example bone versus lung, may be significantly different. Certain tissues may act as "pharmacological sanctuaries" that protect cancer cells from available therapies due to barriers that prevent access to those cells. Evidence suggests that at least some brain metastases are shielded from pharmacologic intervention by the blood-brain barrier $^{36}$. To cure patients of metastatic disease, effective therapies will have to be deliverable to all of the potential metastatic sites within the body. Since microenvironments differ in various secondary sites, combination anti-metastasis therapies may be necessary to deal with both intra-tumoral genetic heterogeneity as well as microenvironmentallyinduced heterogeneity.

In summary, current adjuvant therapies are expected to control metastasis by targeting residual disease remaining after surgery. However, the use of adjuvant therapy is estimated to reduce the relative risk of relapse by only $19-37 \%$ depending on the age of the patient ${ }^{37}$. Thus, neither the current cytotoxic nor targeted adjuvant approaches appear to be as effective at preventing metastases as they are at targeting the primary tumor. Finding new molecular targets for preventing the growth of metastatic tumors should be based on the realization of how different this process is from early tumorigenesis.

\section{Take-home lessons for optimal design of future anti- metastatic therapies}

Based on our current knowledge of metastasis biology, we envision a three-pronged strategy for clinical intervention for progressive disease: prevention, stasis, and destruction. The prevention arm would be primarily applied as a neo-adjuvant therapy intended to reduce the potential metastatic capacity of tumor cells naturally shed from the primary tumor between diagnosis and surgical removal. As discussed above, this might require combination therapy for maximal efficiency since it has been demonstrated that tumor cells use multiple motility mechanisms (amoeboid, epithelial-to-mesenchymal transition, collective migration ${ }^{38}$ ) to initiate dissemination. This arm might also be used to help suppress potential metastatic cells displaced during surgical resection itself. Since breast cancers undergo early dissemination, the prevention strategy would not necessarily be effective against cells that disseminated to distant sites prior to diagnosis. For these cells, cytostatic or cytotoxic therapies need to be developed, specific to the biology of disseminated cells, to either hold the disseminated cells in a sub-clinical state for the remaining natural lifetime of the patient, or to eliminate the metastatic "seed" before it can establish clinically relevant lesions. Finally, for those patients unfortunate enough to develop metastases, therapeutics specifically developed and targeted to metastatic biology need to be developed to reduce morbidity and mortality associated with these secondary tumors.

For these strategies to work, appropriate targets that drive the establishment and maintenance of metastasis have to be identified. Regrettably, despite significant advances in our understanding of the cellular biology of metastatic disease, our knowledge of metastasis "driver" genes remains limited. This is due partially to the difficulty of studying the process, since much of the important biology occurs in a small fraction of disseminated single cells or micrometastases. At present, it is not possible to easily identify those cells that will evolve into macroscopic lesions for in depth analysis, or exactly when that critical event occurs. In addition, metastatic samples are difficult to obtain from human patients since they are not usually resected, but instead are subject to systemic therapy. Thus, although the common mutations that drive primary breast cancer are now known thanks to large sequencing projects, much less is known about the mutational spectrum in metastatic disease. Finally, there may be many genes that are associated with metastatic progression. Analysis of gene expression-based prognostic signatures suggests that there may be hundreds or even thousands of genes whose expression is correlated with the disease outcome ${ }^{39}$. Many of these genes are most likely expressed in the tumor microenvironment and therefore investigations solely in tumor cells have the potential to miss important molecules targetable for clinical intervention.

Continued investigations based on the biology of primary tumors for the development of novel therapeutics are clearly important, and undoubtedly will provide additional benefit to patients. However, this strategy is potentially fraught with dangers, since therapies that can shrink primary tumors have been shown to have little effect, or even potentially adverse effects, on metastatic disease ${ }^{40,41}$. Furthermore, work from many laboratories has identified metastasis-associated genes that are not frequently mutated during cancer progression but are epigenetically silenced or exert their metastatic influence through alterations at the transcriptional level. Our own laboratory uses a meiotic genetics approach to identify somatically inherited polymorphisms that affect patients' susceptibility to metastasis. This approach has generated a growing list of metastasis susceptibility genes with tumor-autonomous or stromal effects, including some with the potential to be actionable clinical targets ${ }^{42-48}$. The results of these studies suggest that a more comprehensive examination of metastasis biology, incorporating both genomic and transcriptional landscape mapping, may provide an entirely different set of genes that might be more advantageously targeted to specifically reduce metastatic burden, without necessarily impacting the primary tumor.

Now that The Cancer Genome Atlas (TCGA) and other genomics projects have provided detailed information regarding the etiology of primary tumors, it is time to initiate similar projects for metastatic disease. Since metastatic tumors represent highly selected cells from a subset of the primary tumor localized in completely different microenvironments, these lesions should be recognized as 
related (but distinct) tumors with different biology. Thus, treatment strategies that are developed based on specific features of metastasis biology, used in parallel with those designed against the primary tumor, will provide a more effective method for combatting the final lethal stages of neoplastic disease than those strategies developed solely against the primary tumor. A Metastasis Genome Atlas Project would, however, have additional challenges compared to the TCGA. The major challenge would be access to the metastatic tumor samples since surgical resection of metastases is usually not performed due to increased risk without perceived patient benefit. In addition, metastatic tissue collected postmortem may be compromised or selected by therapies that potentially induce genomic changes, complicating analysis and interpretation of the results.
Furthermore, it will be important to screen multiple metastases from different secondary sites within individual patients to help identify tissue-specific differences that might expose therapeutic vulnerabilities or resistance. Regardless of the challenges facing the Metastasis Genome Atlas Project concept, improved therapeutic strategies to reduce breast cancer morbidity and mortality would significantly benefit from a better understanding of the biology underlying the primary cause of patient distress, disseminated metastatic disease.

Grant information

The author(s) declared that no grants were involved in supporting this work.
1. Howlader N, Noone AM, Krapcho M, et al.: SEER Cancer Stat Rev, 1975-2011. 2014 Reference Source

2. Lu J, Steeg PS, Price JE, et al:: Breast cancer metastasis: challenges and opportunities. Cancer Res. 2009; 69(12): 4951-3. PubMed Abstract | Publisher Full Text

3. Watson IR, Takahashi K, Futreal PA, et al.: Emerging patterns of somatic mutations in cancer. Nat Rev Genet. 2013; 14(10): 703-18. PubMed Abstract | Publisher Full Text | Free Full Text

4. Greaves M, Maley CC: Clonal evolution in cancer. Nature. 2012; 481(7381): 306-13. PubMed Abstract | Publisher Full Text | Free Full Text

5. $\quad \mathrm{F}$ Perou $\mathrm{CM}$, Sørlie T, Eisen MB, et al.: Molecular portraits of human breast tumours. Nature. 2000; 406(6797): 747-52. PubMed Abstract | Publisher Full Text | F1000 Recommendation

6. $\quad F$ van de Vijver MJ, He YD, van't Veer LJ, et al.: A gene-expression signature as a predictor of survival in breast cancer. N Engl J Med. 2002; 347(25): 1999-2009. PubMed Abstract | Publisher Full Text | F1000 Recommendation

7. Eckhardt BL, Francis PA, Parker BS, et al:: Strategies for the discovery and development of therapies for metastatic breast cancer. Nat Rev Drug Discov. 2012; 11(6): 479-97.

PubMed Abstract | Publisher Full Text

8. F Early Breast Cancer Trialists' Collaborative Group. Effects of chemotherapy and hormonal therapy for early breast cancer on recurrence and 15-year survival: an overview of the randomised trials. Lancet. 2005; 365(9472): 1687-717. PubMed Abstract | Publisher Full Text | F1000 Recommendation

9. $\mathrm{F}$ Zhang $\mathrm{XH}$, Wang $\mathrm{Q}$, Gerald $\mathrm{W}$, et al.: Latent bone metastasis in breast cancer tied to Src-dependent survival signals. Cancer cell. 2009; 16(1): 67-78. PubMed Abstract | Publisher Full Text | Free Full Text | F1000 Recommendation

10. F Marshall JC, Collins JW, Nakayama J, et al.: Effect of inhibition of the lysophosphatidic acid receptor 1 on metastasis and metastatic dormancy in breast cancer. J Natl Cancer Inst. 2012; 104(17): 1306-19. PubMed Abstract | Publisher Full Text | Free Full Text | F1000 Recommendation

11. F Sosa MS, Avivar-Valderas A, Bragado $P$, et al:: ERK1/2 and $p 38 \alpha / \beta$ signaling in tumor cell quiescence: opportunities to control dormant residual disease. Clin Cancer Res. 2011; 17(18): 5850-7.

PubMed Abstract | Publisher Full Text | Free Full Text | F1000 Recommendation

12. F El Touny LH, Vieira A, Mendoza A, et al:: Combined SFK/MEK inhibition prevents metastatic outgrowth of dormant tumor cells. J Clin Invest. 2014; 124(1): 156-68.

PubMed Abstract | Publisher Full Text | Free Full Text | F1000 Recommendation

13. F Ferretti G, Bria E, Giannarelli D, et al.: Second- and third-generation aromatase inhibitors as first-line endocrine therapy in postmenopausa metastatic breast cancer patients: a pooled analysis of the randomised trials. Br J Cancer. 2006; 94(12): 1789-96.

PubMed Abstract | Publisher Full Text | Free Full Text | F1000 Recommendation

14. Rimawi MF, Schiff R, Osborne CK: Targeting HER2 for the Treatment of Breast

Cancer. Annu Rev Med. 2015; 66: 111-28.

PubMed Abstract | Publisher Full Text
15. Nguyen DX, Bos PD, Massagué J: Metastasis: from dissemination to organ-specific colonization. Nat Rev Cancer. 2009; 9(4): 274-84. PubMed Abstract | Publisher Full Text

16. Mina LA, Sledge GW Jr: Rethinking the metastatic cascade as a therapeutic target. Nat Rev Clin Oncol. 2011; 8(6): 325-32. PubMed Abstract | Publisher Full Text

17. $\mathrm{F}$ Kim MY, Oskarsson T, Acharyya S, et al.: Tumor self-seeding by circulating cancer cells. Cell. 2009; 139(7): 1315-26. PubMed Abstract | Publisher Full Text | Free Full Text | F1000 Recommendation

18. F Wang SH, Lin SY: Tumor dormancy: potential therapeutic target in tumor recurrence and metastasis prevention. Exp Hematol Oncol. 2013; 2(1): 29. PubMed Abstract | Publisher Full Text | Free Full Text | F1000 Recommendation

19. F Romero I, Garrido F, Garcia-Lora AM: Metastases in immune-mediated dormancy: a new opportunity for targeting cancer. Cancer Res. 2014; 74(23): 6750-7.

PubMed Abstract | Publisher Full Text | F1000 Recommendation

20. F Schaap-Nutt A, Thyssen DA, Drell DW, et al.: Anti-metastatics: an overview of drug candidates in current pipelines. Curr Pharm Des. 2014; 20(42) 6522-8.

PubMed Abstract | Publisher Full Text | F1000 Recommendation

21. $F$ Hüsemann $Y$, Geigl JB, Schubert $F$, et al:: Systemic spread is an early step in breast cancer. Cancer cell. 2008; 13(1): 58-68. PubMed Abstract | Publisher Full Text | F1000 Recommendation

22. F Cutuli B, Cohen-Solal-Le Nir C, De Lafontan B, et al:: Ductal carcinoma in situ of the breast results of conservative and radical treatments in 716 patients. Eur J Cancer. 2001; 37(18): 2365-72. PubMed Abstract | F1000 Recommendation

23. F van de Wouw AJ, Janssen-Heijnen ML, Coebergh JW, et al.: Epidemiology of unknown primary tumours; incidence and population-based survival of 1285 patients in Southeast Netherlands, 1984-1992. Eur J Cancer. 2002; 38(3): 409-13.

PubMed Abstract | F1000 Recommendation

24. Riethmüller G, Klein CA: Early cancer cell dissemination and late metastatic relapse: clinical reflections and biological approaches to the dormancy problem in patients. Semin Cancer Biol. 2001; 11(4): 307-11. PubMed Abstract | Publisher Full Text

25. F Aguirre-Ghiso JA: Models, mechanisms and clinical evidence for cancer dormancy. Nat Rev Cancer. 2007; 7(11): 834-46. PubMed Abstract | Publisher Full Text | Free Full Text | F1000 Recommendation

26. Sosa MS, Bragado P, Aguirre-Ghiso JA: Mechanisms of disseminated cancer cell dormancy: an awakening field. Nat Rev Cancer. 2014; 14(9): 611-22. PubMed Abstract | Publisher Full Text | Free Full Text

27. F Naumov GN, Townson JL, MacDonald IC, et al:: Ineffectiveness of doxorubicin treatment on solitary dormant mammary carcinoma cells or late-developing metastases. Breast Cancer Res Treat. 2003; 82(3): 199-206. PubMed Abstract | Publisher Full Text | F1000 Recommendation

28. Welch DR: Microarrays bring new insights into understanding of breast cancer metastasis to bone. Breast Cancer Res. 2004; 6(2): 61-4. PubMed Abstract | Publisher Full Text | Free Full Text 
29. F Aurilio G, Disalvatore D, Pruneri G, et al.: A meta-analysis of oestrogen receptor, progesterone receptor and human epidermal growth factor receptor 2 discordance between primary breast cancer and metastases. Eur $\mathrm{J}$ Cancer. 2014; 50(2): 277-89.

PubMed Abstract | F1000 Recommendation

30. Butler TP, Gullino PM: Quantitation of cell shedding into efferent blood of mammary adenocarcinoma. Cancer Res. 1975; 35(3): 512-6. PubMed Abstract

31. F Luzzi KJ, MacDonald IC, Schmidt EE, et al:: Multistep nature of metastatic inefficiency: dormancy of solitary cells after successful extravasation and limited survival of early micrometastases. Am J Pathol. 1998; 153(3): 865-73. PubMed Abstract | Publisher Full Text | Free Full Text | F1000 Recommendation

32. Valastyan $\mathrm{S}$, Weinberg RA: Tumor metastasis: molecular insights and evolving paradigms. Cell. 2011; 147(2): 275-92. PubMed Abstract | Publisher Full Text | Free Full Text

33. Klein CA: Parallel progression of primary tumours and metastases. Nat Rev Cancer. 2009; 9(4): 302-12.

PubMed Abstract | Publisher Full Text

34. F Gancberg D, Di Leo A, Cardoso F, et al.: Comparison of HER-2 status between primary breast cancer and corresponding distant metastatic sites. Ann Oncol. 2002; 13(7): 1036-43. PubMed Abstract | Publisher Full Text | F1000 Recommendation

35. F Almendro V, Kim HJ, Cheng YK, et al:: Genetic and phenotypic diversity in breast tumor metastases. Cancer Res. 2014; 74(5): 1338-48. PubMed Abstract | Publisher Full Text | Free Full Text | F1000 Recommendation

36. Lin NU, Amiri-Kordestani L, Palmieri D, et al.: CNS metastases in breast cancer: old challenge, new frontiers. Clin Cancer Res. 2013; 19(23): 6404-18. PubMed Abstract | Publisher Full Text

37. Singh AK, Loscalzo J, Brigham and Women's Hospital: The Brigham intensive review of internal medicine. New York: Oxford University Press; 2012. Reference Source

38. Friedl P, Alexander S: Cancer invasion and the microenvironment: plasticity and reciprocity. Cell. 2011; 147(5): 992-1009. PubMed Abstract | Publisher Full Tex

39. F Ein-Dor L, Kela I, Getz G, et al:: Outcome signature genes in breast cancer: is there a unique set? Bioinformatics. 2005; 21(2): 171-8. PubMed Abstract | Publisher Full Text | F1000 Recommendation

40. F Biswas S, Guix M, Rinehart C, et al:: Inhibition of TGF-beta with neutralizing antibodies prevents radiation-induced acceleration of metastatic cancer progression. J Clin Invest. 2007; 117(5): 1305-13.

PubMed Abstract | Publisher Full Text | Free Full Text | F1000 Recommendation

41. F Alsarraj J, Faraji F, Geiger TR, et al.: BRD4 short isoform interacts with RRP1B, SIPA1 and components of the LINC complex at the inner face of the nuclear membrane. PloS One. 2013; 8(11): e80746. PubMed Abstract | Publisher Full Text | Free Full Text | F1000 Recommendation

42. Park YG, Zhao $X$, Lesueur $F$, et al:: Sipa1 is a candidate for underlying the metastasis efficiency modifier locus Mtes1. Nat Genet. 2005; 37(10): 1055-62. PubMed Abstract | Publisher Full Text | Free Full Text

43. Crawford NP, Alsarraj J, Lukes L, et al:: Bromodomain 4 activation predicts breast cancer survival. Proc Natl Acad Sci U S A. 2008; 105(17): 6380-5. PubMed Abstract | Publisher Full Text | Free Full Text

44. Crawford NP, Qian X, Ziogas A, et al.: Rrp1b, a new candidate susceptibility gene for breast cancer progression and metastasis. PLoS Genet. 2007; 3(11): e214.

PubMed Abstract | Publisher Full Text | Free Full Text

45. F Crawford NP, Walker RC, Lukes L, et al:: The Diasporin Pathway: a tumor progression-related transcriptional network that predicts breast cancer survival. Clin Exp Metastasis. 2008; 25(4): 357-69.

PubMed Abstract | Publisher Full Text | Free Full Text | F1000 Recommendation

46. Faraji F, Hu Y, Wu G, et al:: An integrated systems genetics screen reveals the transcriptional structure of inherited predisposition to metastatic disease. Genome Res. 2014; 24(2): 227-40.

PubMed Abstract | Publisher Full Text | Free Full Text

47. Winter SF, Lukes L, Walker RC, et al.: Allelic variation and differential expression of the mSIN3A histone deacetylase complex gene Arid4b promote mammary tumor growth and metastasis. PLoS Genet. 2012; 8(5): e1002735. PubMed Abstract | Publisher Full Text | Free Full Text

48. Faraji F, Pang Y, Walker RC, et al.: Cadm1 is a metastasis susceptibility gene that suppresses metastasis by modifying tumor interaction with the cell-mediated immunity. PLoS Genet. 2012; 8(9): e1002926. PubMed Abstract | Publisher Full Text | Free Full Text 


\section{Open Peer Review}

\section{Current Peer Review Status:}

\section{Version 1}

Reviewer Report 04 June 2015

https://doi.org/10.5256/f1000research.6592.r8900

(C) 2015 Anderson R. This is an open access peer review report distributed under the terms of the Creative Commons Attribution License, which permits unrestricted use, distribution, and reproduction in any medium, provided the original work is properly cited.

\section{Robin L. Anderson}

Peter MacCallum Cancer Centre, East Melbourne, Victoria, 3002, Australia

Competing Interests: No competing interests were disclosed.

I confirm that I have read this submission and believe that I have an appropriate level of expertise to confirm that it is of an acceptable scientific standard.

Reviewer Report 04 June 2015

https://doi.org/10.5256/f1000research.6592.r8899

(C) 2015 Welch D. This is an open access peer review report distributed under the terms of the Creative Commons Attribution License, which permits unrestricted use, distribution, and reproduction in any medium, provided the original work is properly cited.

\section{Danny Welch}

University of Kansas Medical Center, Kansas City, KS, 66160, USA

This is a well-written perspective that deals with the challenges and opportunities of treating/preventing breast cancer metastasis. The manuscript is fair, balanced and covers the majority of issues relevant to the topic.

Competing Interests: No competing interests were disclosed.

I confirm that I have read this submission and believe that I have an appropriate level of expertise to confirm that it is of an acceptable scientific standard. 
Reviewer Report 04 June 2015

https://doi.org/10.5256/f1000research.6592.r8898

(C) 2015 Eccles S. This is an open access peer review report distributed under the terms of the Creative Commons Attribution License, which permits unrestricted use, distribution, and reproduction in any medium, provided the original work is properly cited.

\section{Suzanne A Eccles}

The Institute of Cancer Research, Sutton, London, SM2 5NG, UK

Dr Hunter and colleagues have written an excellent, very timely and thought-provoking paper outlining the key issues in tackling metastatic breast cancer. It is almost unique in its ability to appear years or even decades after successful treatment of the primary tumor. They accurately pinpoint our failures so far to control metastatic disease and suggests that a '3-pronged attack' will be required to improve survival: prevention of further spread, eradication of (or maintenance of dormancy in) disseminated cells and, most important of all, destruction of established micrometastases.

The latter is certainly the main challenge: most primary breast cancers are successfully and completely removed by surgery, it is the already-disseminated tumor cells (DTC) that are the potential seeds of destruction of a human life. Much attention has been given to the early stages of metastasis: release of cells, motility, invasion, adhesion to endothelia, extravasation - perhaps because these steps are the easiest to manipulate experimentally. The onus is now on scientists to address whether any of these processes and their molecular mediators are still required once DTC are established at secondary sites. We need to know if they represent the 'starter motor' (essential initially but redundant once the process is underway) or the 'engine' (powering the continued progress) of metastases. Even if we can prevent further spread, it is important to define whether existing micrometastases (probably generated very early in the course of the disease) would prove fatal before any later waves of circulating cells take hold - possibly a case of shutting the stable door after the horse has bolted.

Metastases break one of the fundamental 'taboos' of multicellular organisms - that of cells being able to survive and thrive in quite disparate, alien tissue environments - they no longer 'know their place'. If we could define how this is achieved we may discover some common denominator actionable molecular targets for intervention that could be effective against widespread metastatic disease. Such studies, with the precision tools of genetic manipulation could perhaps be achieved in lower organisms as a starting point.

So, key additional questions raised by this interesting piece are: which if any of the molecular mechanisms required to initiate and maintain primary tumors are also essential for establishing metastases and for how long do any such dependencies persist? Or are the determinants of successful secondary colonisation quite distinct? Do different organs have similar or unique requirements that enable cancer cells to form overt metastases? The paper touches on these considerations, but much more research is required in this challenging area. It is therefore essential, as Hunter rightly states, to facilitate better access to clinical material, especially relapsed and drug resistant secondary disease (which may only be practical at autopsy). 
Dr Hunter's paper will certainly recalibrate the way we think about translational research in metastasis. It should inspire new generations of basic scientists and clinicians to work together to tackle more logically and effectively this last hurdle in our efforts to improve cure rates in breast and other cancers.

Competing Interests: No competing interests were disclosed.

I confirm that I have read this submission and believe that I have an appropriate level of expertise to confirm that it is of an acceptable scientific standard.

Reviewer Report 04 June 2015

https://doi.org/10.5256/f1000research.6592.r8897

(C) 2015 Chambers A. This is an open access peer review report distributed under the terms of the Creative Commons Attribution License, which permits unrestricted use, distribution, and reproduction in any medium, provided the original work is properly cited.

\section{Ann Chambers}

London Regional Cancer Centre, London, Ontario, N6A 4L6, Canada

This is a thoughtful and well-written short review of a clinically very important topic. This review presents a synthesis of approaches to deal clinically with metastatic breast cancer, and will stimulate thought in the field.

Competing Interests: No competing interests were disclosed.

I confirm that I have read this submission and believe that I have an appropriate level of expertise to confirm that it is of an acceptable scientific standard.

Reviewer Report 04 June 2015

\section{https://doi.org/10.5256/f1000research.6592.r8896}

(C) 2015 Steeg P. This is an open access peer review report distributed under the terms of the Creative Commons Attribution License, which permits unrestricted use, distribution, and reproduction in any medium, provided the original work is properly cited.

\section{Patricia Steeg}

Center for Cancer Research, National Cancer Institute, Bethesda, MD, 20892, USA

Competing Interests: No competing interests were disclosed. 
I confirm that I have read this submission and believe that I have an appropriate level of expertise to confirm that it is of an acceptable scientific standard.

The benefits of publishing with F1000Research:

- Your article is published within days, with no editorial bias

- You can publish traditional articles, null/negative results, case reports, data notes and more

- The peer review process is transparent and collaborative

- Your article is indexed in PubMed after passing peer review

- Dedicated customer support at every stage

For pre-submission enquiries, contact research@f1000.com 